УДК 616.45-001.1/3:612.123:616-053.7/.84:612.8

DOI 10.11603/24116-4944.2017.2.8095

๑Вл. В. Подольський, В. В. Подольський

Державна установа «Інститут педіатрії, акушерства і гінекологї Національної академї медичних наук України», Київ

\title{
ПЕРЕКИСНЕ ОКИСЛЕННЯ ЛІПІДІВ ЯК ПРОЯВ ОКСИДАТИВНОГО СТРЕСУ В ОРГАНІЗМІ ЖІНОК ІЗ ЗМІНАМИ РЕПРОДУКТИВНОГО ЗДОРОВ'Я НА ТЛІ СОМАТОФОРМНИХ ЗАХВОРЮВАНЬ ІЗ ПОРУШЕННЯМИ ВЕГЕТАТИВНОГО ГОМЕОСТАЗУ
}

\begin{abstract}
Мета дослідження - вивчення вмісту фросфоліпідів та нейтральних ліпідів клітин крові в жінок фрертильного віку зі змінами репродуктивного здоров'я та порушеннями вегетативного гомеостазу.

Матеріали та методи. Було клінічно обстежено 360 жінок із змінами репродуктивного здоров'я у вигляді станів після перенесених артифріційних абортів, безпліддя та лейоміоми матки і порушень вегетативного гомеостазу, які проявлялись синдромом вегетативної дисфункції і соматоформною дисфункцією вегетативної нервової системи - за гіпертонічним, гіпотонічним та кардіальним типами.

Результати дослідження та їх обговорення. У жінок із змінами репродуктивного здоров'я на тлі порушень вегетативного гомеостазу відбувається активація перекисного окислення ліпідів. При різних видах порушень вегетативного гомеостазу та різних змінах репродуктивного здоров'я активація перекисного окислення ліпідів відбувається по-різному. Більш інтенсивно цей процес, за результатами наших досліджень, відбувався у жінок зі всіма видами порушень вегетативного гомеостазу, що перенесли артифіційний аборт.
\end{abstract}

Висновок. Оксидативний стрес $€$ важливим патогенетичним механізмом розвитку змін репродуктивного здоров'я у жінок із соматоформними захворюваннями та порушенням вегетативного гомеостазу.

Ключові слова: порушення вегетативного гомеостазу; зміни репродуктивного здоров'я; перекисне окислення ліпідів; оксидативний стрес.

ПЕРЕКИСНОЕ ОКИСЛЕНИЕ ЛИПИДОВ КАК ПРОЯВЛЕНИЕ ОКСИДАТИВНОГО СТРЕССА В ОРГАНИЗМЕ ЖЕНЩИН С ИЗМЕНЕНИЯМИ РЕПРОДУКТИВНОГО ЗДОРОВЬЯ НА ФОНЕ СОМАТОФОРМНЫХ ЗАБОЛЕВАНИЙ С НАРУШЕНИЯМИ ВЕГЕТАТИВНОГО ГОМЕОСТАЗА

Цель исследования - изучение содержания фоосфолипидов и нейтральных липидов клеток крови у женщин фрертильного возраста с изменениями репродуктивного здоровья и нарушениями вегетативного гомеостаза.

Материалы и методы. Было клинически обследовано 360 женщин с изменениями репродуктивного здоровья в виде состояний после перенесенных артифициальных абортов, бесплодия и лейомиомы матки и нарушений вегетативного гомеостаза, которые проявлялись синдромом вегетативной дисфункции и соматоформной дисфункцией вегетативной нервной системы - по гипертоническому, гипотоническому и кардиальному типах.

Результаты исследования и их обсуждение. У женщин с изменениями репродуктивного здоровья на фоне нарушений вегетативного гомеостаза происходит активация перекисного окисления липидов. При различных видах нарушений вегетативного гомеостаза и различных изменениях репродуктивного здоровья активация перекисного окисления липидов происходит по-разному. Более интенсивно этот процесс, по результатам наших исследований, происходил у женщин со всеми видами нарушений вегетативного гомеостаза, перенесших артифициальный аборт.

Вывод. Оксидативный стресс является важным патогенетическим механизмом развития изменений репродуктивного здоровья у женщин с соматоформными заболеваниями и нарушениями вегетативного гомеостаза.

Ключевые слова: нарушения вегетативного гомеостаза; изменения репродуктивного здоровья; перекисное окисление липидов; оксидативный стресс.

LIPID PEROXIDATION, AS A RESULT OF OXIDATIVE STRESS IN WOMEN WITH CHANGES OF REPRODUCTIVE HEALTH ON THE BACKGROUND OF SOMATOFORM DISEASES WITH VIOLATIONS OF AUTONOMIC HOMEOSTASIS

The aim of the study - to learn the the content of phospholipids and neutral lipids of blood cells in women of childbearing age with changes in reproductive health and disorders of autonomic homeostasis.

Materials and Methods. We examined 360 women with changes in reproductive health that had an artificial abortion, infertility or uterine leiomyoma and such violation of autonomic homeostasis as autonomic dysfunction syndrome, somatoform dysfunction of autonomic nervous system by hypertonic, hypotonic and cardiac type.

Results and Discussion. We found activation of lipid peroxiadtion in women with changes of reproductive health and violations of the autonomic homeostasis. Different types of autonomic homeostasis violations in combination with changes in reproductive health causes different types of lipid peroxidation activation. According to our data most intensive lipid peroxidation was found in women with all studied violations of autonomic homeostasis, who had an artificial abortion.

Conclusions. Oxidative stress is an important pathogenetic mechanism in development of changes in reproductive health in women with somatoform diseases and violations of autonomic homeostasis.

Key words: violations of autonomic homeostasis; changes in reproductive health; lipid peroxidation; oxidative stress. 
ВстУп. Вегетативна нервова система забезпечує регуляцію роботи внутрішніх органів, кровоносних і лімфатичних судин та залоз. Крім того, вона бере участь у забезпеченні гомеостазу організму, різних фрорм фрізичної і психічної діяльності, у роботі серцево-судинної та дихальної систем організму, впливає на діяльність ендокринної системи. Така багатофункціональність вегетативної нервової системи в організмі, безумовно, впливає і на стан репродуктивної системи жінки $[1,2]$. Зміни в стані вегетативного гомеостазу можуть призводити до порушення енергетичного обміну і процесів енергозабезпечення, що може стати стимулятором розвитку оксидативного стресу (OC).

Відомо, що деякі патологічні стани ведуть до активації нейтрофілів, і супроводжуються підсиленням ОС [3].

В організмі людини ОС може виникати на тлі багатьох чинників і бути в тому числі результатом перекисного окислення ліпідів (ПОЛ), який є окислювальною деградацією ліпідів, що відбувається, в основному, під дією вільних радикалів [4].

У числі продуктів цього процесу - малондіальдегід і 4-гідроксиноненал.

Реакції біологічного окислення супроводжуються утворенням вільних радикалів - частинок, що мають на зовнішній валентній орбіталі неспарені електрони. Це обумовлює високу хімічну активність цих радикалів. Наприклад, вони вступають у реакцію з ненасиченими жирними кислотами мембран, порушуючи їх структуру. Антиоксиданти запобігають вільнорадикальному окисленню [4].

Через стадію перекисних похідних ненасичених жирних кислот здійснюється біосинтез простагландинів і лейкотрієнів, а тромбоксани, які надають потужний вплив на адгезивно-агрегаційні властивості фрормених елементів крові та мікроциркуляцію, самі $€$ продуктом реакції перетворення гідроперекисів. Окислення гідроперекисів холестерину - одна з ланок у синтезі деяких стероїдних гормонів, зокрема прогестерону [5-7].

Реакції пОЛ є вільнорадикальними і постійно перебігають в організмі, також як і реакції утворення активних фрорм кисню (АФК). У нормі вони підтримуються на певному рівні і виконують ряд функцій, зокрема: індукують апоптоз (запрограмовану загибель клітин), регулюють структуру клітинних мембран і тим самим забезпечують фрункціонування іонних каналів, рецепторів, фрерментних систем; забезпечують звільнення з мембрани арахідонової кислоти, з якої синтезуються біорегулятори (простагландини, тромбоксани, лейкотрієни), ПОЛ може виступати в якості вторинного месенджера, беручи участь у трансорормації сигналів із зовнішнього і внутрішнього середовищ організму, забезпечуючи їх внутрішньоклітинну передачу, АФК беруть участь у клітинному імунітеті і фрагоцитозі [8].

У результаті пол відбувається перетворення звичайних ліпідів у первинні продукти пОЛ (гідроперекиси ліпідів). Це призводить до появи в мембранах ділянок («дірок»), через які назовні виходить вміст як самих клітин, так і їх органел [8].

Первинні продукти ПОЛ руйнуються з утворенням вторинних продуктів ПОЛ: альдегідів, кетонів, малонового діальдегіду (МДА), дієнових кон'югатів. Накопиченням у крові МДА пояснюється синдром інтоксикації, що супро- воджує багато захворювань внутрішніх органів. Реагуючи $3 \mathrm{SH}-$ і CH3-групами білків, МДА пригнічує активність цитохромоксидази (пригнічуючи тим самим тканинне дихання) і гідроксилази. МДА обумовлює також прискорений розвиток атеросклерозу [8].

При взаємодії МДА з аміногрупами фоссроліпідів утворюються кінцеві продукти ПОЛ - шифрфові основи.

Негативні наслідки активації пол проявляються: у пошкодженні ліпідного бішару мембран, у результаті чого в клітини проникає вода, іони натрію, кальцію, що призводить до набухання клітин, органел і їх руйнування, в передчасному старінні клітин і організму в цілому, у зміні плинності (в'язкості) мембран, у результаті чого порушується транспортна фрункція мембран (фрункціонування іонних каналів), у порушенні активності мембранозв'язаних форментів, рецепторів [8].

Активація ПОЛ характерна для багатьох захворювань і патологічних станів, таких, як: атеросклероз та інші серцево-судинні захворювання, запальні процеси будьякого генезу [8].

Стрес i, зокрема, стресові гормони мають значний вплив на розвиток в організмі вільнорадикального окислення, цей процес може викликати пошкодження мітохондріальних мембран. При пошкодженні мітохондріальних мембран знижується ефрективність окисного фросфорилювання (тканинного дихання), що веде до зменшення аеробного енергозабезпечення м'язової роботи [9].

Наведені результати досліджень дозволяють вважати процеси вільнорадикального окислення, і, в першу чергу, ліпідів біологічних мембран, найважливішим дезадаптаційним фрактором, що обумовлює розвиток стомлення і зниження фрізичної працездатності [9].

Одним із компонентів ПОЛ є дієнові кон'югати, які $€$ первинними продуктами ПОЛ. При вільнорадикальному окисненні арахідонової кислоти відбувається відрив водню в $\alpha$-положенні по відношенню до подвійного зв'язку, що призводить до переміщення цього подвійного зв'язку з утворенням дієнових кон'югат [10, 11]. Дієнові кон'югати, які $€$ первинними продуктами ПОЛ, відносяться до токсичних метаболітів, які мають пошкоджуючу дію на ліпопротеїди, білки, ферменти і нуклеїнові кислоти [12-14].

Ліпопероксиди є досить нестійкими і піддаються подальшій окисній дегенерації. При цьому накопичуються вторинні продукти окислення, найбільш важливими 3 яких є ненасичені альдегіди (МДА). Продуктами взаємодії малонового діальдегіду 3 аміновмісними сполуками $€$ шисрсові основи [15].

ТБК-реактанти (МДА) - вторинні продукти ПОЛ. Як відомо, МДА утворюється тільки з жирних кислот з трьома і більше подвійними зв'язками. МДА належить важлива роль у синтезі простагландинів, прогестерону та інших стероїдів $[10,12]$. Негативна роль малонового діальдегіду полягає в тому, що він зшиває молекули ліпідів і знижує плинність мембрани. Внаслідок цього мембрана стає більш крихкою. Порушуються процеси, пов'язані зі зміною поверхні мембрани: фрагоцитоз, піноцитоз, клітинна міграція та ін. [10, 12].

Спектри кон'югованих гідроперекисів поліненасичених жирних кислот характеризуються інтенсивним поглинанням в ультрафріолетовій області спектра з максимумом при 232-234 нм. Визначення вмісту дієнових кон'югат проводили в екстрактах еритроцитів [16]. 
Відомо, що малоновий діальдегід в крові - це один із показників активності ПОЛ [17]. Основні показання до застосування: захворювання серцево-судинної системи, атеросклероз, діабет. МДА - один із кінцевих продуктів перекисного окислення ліпідів, тобто є продуктом розщеплення жирних кислот. У свою чергу, цей альдегід утворює шифрфові основи з аміногрупами білків, у результаті чого утворюються нерозчинні ліпід-білкові комплекси, які іноді називають «пігментами зношування» (Ліпофусцин). За швидкістю окислення малонового альдегіду можна робити висновки про активацію ПОЛ. МДА - ендогенний альдегід, який $є$ клініко-лабораторним маркером ОС і використовуваний для прогнозу та контролю лікування ішемічної хвороби серця, а також широкого спектра інших захворювань [17].

МДА утворюється в результаті метаболізму арахідонової та інших поліненасичених жирних кислот. Внаслідок подальших біохімічних перетворень він окислюється до діоксиду вуглецю або вступає у взаємодію 3 фосороліпідами, амінокислотами і нуклеїновими кислотами. В даний час МДА розглядається в якості маркера ОС [18].

Найбільш значущий зв'язок виявлено між МДА і концентрацією ліпопротеїнів дуже низької щільності, а також тригліцеридів і загального холестерину [18].

Важкий перебіг захворювань пов'язаний із найбільш високими показниками МДА [18].

Тому зміни в стані пОЛ, які призводять до розвитку ОС, можуть віддзеркалювати взаємозв'язок змін репродуктивного здоров'я (3Р3) з порушеннями вегетативного гомеостазу (ПВГ) в організмі ЖФВ.

МЕТА ДОСЛІДЖЕННЯ - вивчення вмісту фросфроліпідів та нейтральних ліпідів клітин крові у ЖФВ із ЗРЗ та ПВГ.

МАТЕРІАЛИ ТА МЕТОДИ. БУЛо клінічно обстежено 360 жінок із ЗРЗ у вигляді станів після перенесених артифріційних абортів, безпліддя та лейоміоми матки і ПВГ, які проявлялись синдромом вегетативної дисфункції (СВД) і соматоформною диссрункцією вегетативної нервової системи (СДВНС) - за гіпертонічним, гіпотонічним та кардіальним типами. Всі обстежені жінки, таким чином, були розподілені на 4 групи залежно від ПВГ:

І група - жінки з ПВГ у вигляді СВД (90 жінок);

II група - жінки з ПВГ у вигляді СДВНС, які за клінічними проявами мали гіпертонічний тип порушень (90 жінок);

III група - жінки з ПВГу вигляді СДВНС, які за клінічними проявами мали гіпотонічний тип порушень (90 жінок);

IV група - СДВНС, за кардіальним типом порушень (90 жінок).

Крім цього, кожна з перелічених груп була розділена на 3 підгрупи залежно від 3Р3: в 1-шу підгрупу входили ЖФВ, що перенесли артифріційний аборт (30 жінок), у 2-гу підгрупу входили ЖФВ із безпліддям (30 жінок) та в 3-тю підгрупу входили ЖФВ, що мали лейоміому матки (30 жінок). Контрольну групу склали 30 жінок без ПВГ.

Інтенсивність ПОЛ та стан антиоксидантної системи визначали за допомогою дослідження спектрофотометричним методом вмісту гідроперекисів ліпідів [19], МДА за методикою І. Д. Стальної [20, 21].

Оцінку достовірності отриманих даних проводили загальноприйнятим методом за допомогою методу довірчих інтервалів Стьюдента.

РЕЗУЛЬТАТИ ДОСЛІДЖЕННЯ ТА ЇХ ОБГОВОРЕННЯ. Результати наших досліджень, проведених у попередні роки, показали роль стресорних механізмів у розвитку та загострення соматоформних захворювань, які супроводжуються ПВГ у жінок із ЗРЗ. На тлі стресорного впливу на організм виникає психосоматична дизадаптація, що, у свою чергу, призводить до змін у різних системах організму, порушуються їх біологічні взаємозв'язки, наслідком яких $€$ зміни в різних ланках вегетативної нервової системи та регуляції судинного тонусу [22-24].

Численні сучасні дослідження довели роль пол біологічних мембран у складному комплексі реакцій організму, які забезпечують його адаптацію. Зважаючи на результати наших досліджень про зміни в стані вегетативного гомеостазу організму жінок із ЗР3 на тлі соматоформних захворювань, можливо припустити, що патологічний адренергічний вплив через систему ліполізу і фроссоліполізу може активізувати процеси пОЛ, а утворені в результаті цього процесу вільнорадикальні сполуки негативно впливають на біологічні мембрани, що в масштабах цілого організму може призводити до ОС. Результати імунологічних, гормональних та психовегетативних досліджень, проведених нами в попередні роки, опосередковано вказують на наявність ОС в організмі жінок із ПВГ та ЗРЗ.

Оскільки в процесі ПОЛ утворюється широкий спектр вільнорадикальних продуктів, а найбільш показовими індикаторами інтенсивності вільнорадикальних процесів, які характеризують ОС, є продукти початкового окислення ліпідів - гідроперекиси фоссоліпідів та вторинні сполуки, що утворюються в результаті розпаду гідроперекисів, - це дієнові кон'югати та карбонільні сполуки, до яких відноситься малоновий альдегід, саме тому ми зупинились на дослідженні цих показників у жінок із ПВГ та ЗРЗ (табл. 1).

3 наведених у таблиці 1 даних видно, що в жінок із ЗР3 на тлі ПВГ відбувається активація ПОЛ. При різних видах ПВГ та різних ЗРЗ активація ПОЛ відбувається порізному. Більш інтенсивно цей процес, за результатами наших досліджень, відбувався у жінок зі всіма видами ПВГ, що перенесли артифріційний аборт. У жінок із ПВГ у вигляді СВД, що перенесли артифіційний аборт, відмічалося підвищення кількості первинних продуктів ПОЛ та складало 1,8 $\pm 0,2(1,6-1,9)$ мкм/мл. У жінок із СДВНС за гіпертонічним типом, що перенесли артифіційний аборт, показник концентрації первинних продуктів ПОЛ - гідроперекисів також був підвищеним і становив 1,8 $\pm 0,3$ $(1,4-2,1)$ мкм/мл.

3 такою ж інтенсивністю процес утворення гідроперекисів відбувався у жінок із ПВГ у вигляді СДВНС за гіпотонічним типом, що страждали від безпліддя та лейоміоми матки. Достатньо інтенсивним процес утворення гідроперекисів відбувався також у жінок із ПВГ у вигляді СВД та СДВНС за гіпертонічним типом, що страждали від лейоміоми матки, та в жінок із ПВГ у вигляді СДВНС за кардіальним типом, що страждали від безпліддя.

Дослідження розмаху середнього значення вибірок та їх стандартних похибок у жінок із ЗРЗ у вигляді непліддя на тлі СДВНС за гіпотонічним типом (рис. 1) та СДВНС за кардіальним типом (рис. 2) показало, що ці показники знаходяться в різних площинах, а графіки пересікаються лише значеннями стандартних відхилень.

Відомо, що МДА є кінцевим продуктом ПОЛ, тобто продуктом розщеплення жирних кислот, який вступає у взаємодію з фоссроліпідами, амінокислотами та нукле- 
Таблиця 1. Показники перекисного окислення ліпідів у жінок фертильного віку з порушенням вегетативного гомеостазу та змінами репродуктивного здоров'я

\begin{tabular}{|c|c|c|c|}
\hline \multicolumn{2}{|c|}{$\begin{array}{c}\text { Група та підгрупи жінок феертильного віку } \\
3 \text { порушеннями вегетативного гомеостазу } \\
\text { та змінами репродуктивного здоров'я }\end{array}$} & \multicolumn{2}{|c|}{ Показник перекисного окислення ліпідів, мкм/мл } \\
\hline $\begin{array}{c}\text { група обстежених } \\
\text { жінок }\end{array}$ & $\begin{array}{c}\text { підгрупа обстежених } \\
\text { жінок }\end{array}$ & $\begin{array}{c}\text { гідроперекиси } \\
\text { (середнє значення) }\end{array}$ & $\begin{array}{c}\text { МДА } \\
\text { (середнє значення) }\end{array}$ \\
\hline \multirow[t]{3}{*}{ I } & 1 & $1,8 \pm 0,2(1,6-1,9)^{\star}$ & $150,5 \pm 23,2(121,3-179,4)^{*}$ \\
\hline & 2 & $1,4 \pm 0,4(0,8-1,9)^{\star}$ & $155,6 \pm 23,8(117,8-193,5)^{\star}$ \\
\hline & 3 & $1,7 \pm 0,5(1,1-2,4)^{\star}$ & $143,7 \pm 6,7(134,4-153,1)^{\star}$ \\
\hline \multirow[t]{3}{*}{ II } & 1 & $1,8 \pm 0,3(1,4-2,1)^{\star}$ & $130,9 \pm 17,3\left(103,4-158,4^{\star}\right)$ \\
\hline & 2 & $1,5 \pm 0,5(1,1-1,8)^{\star}$ & $135,1 \pm 28,3(111,4-158,7)^{\star}$ \\
\hline & 3 & $1,6 \pm 0,5(1,1-2,2)^{\star}$ & $146,1 \pm 21,6(119,2-172,8)^{\star}$ \\
\hline \multirow{3}{*}{ III } & 1 & $1,8 \pm 0,6(0,4-3,3)^{\star}$ & $130,12 \pm 22,3(74,9-185,4)^{*}$ \\
\hline & 2 & $1,8 \pm 0,6(1,4-2,1)^{\star}$ & $146,2 \pm 16,12(135,9-156,5)^{\star}$ \\
\hline & 3 & $1,8 \pm 0,1(1,7-1,8)^{\star}$ & $159,3 \pm 38,1(-182,2-500,8)^{\star}$ \\
\hline \multirow{3}{*}{ IV } & 1 & $1,8 \pm 0,6(1,1-2,6)^{\star}$ & $146,244 \pm 16,9(125,3-167,2)^{\star}$ \\
\hline & 2 & $1,7 \pm 0,4(1,9-1,9)^{\star}$ & $151,9 \pm 24,8(136,9-166,8)^{\star}$ \\
\hline & 3 & $1,4 \pm 0,7(0,7-1,9)^{\star}$ & $148,78 \pm 35,3(116,1-181,3)^{\star}$ \\
\hline
\end{tabular}

Примітка. * - у дужках наведені довірчі інтервали середніх значень, обчислені відповідно до розподілу Стьюдента.

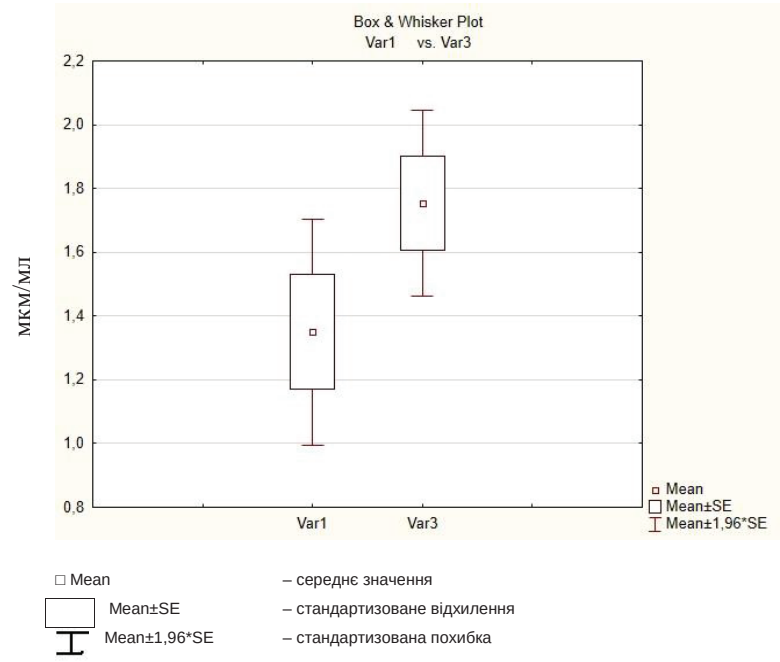

Умовні позначення: Var1 - розмах середнього значення вибірок і їх стандартизовані похибки показника вмісту гідроперекисів у крові жінок із непліддям та соматоформною диссункцією вегетативної нервової системи за гіпотонічним типом; Var3 - розмах середнього значення вибірок і їх стандартизовані похибки показника вмісту гідроперекисів у крові жінок із непліддям та синдромом вегетативної дисорункції.

Рис. 1. Діаграма розмаху середніх значень вибірок та їх стандартизовані похибки показника вмісту гідроперекисів у крові жінок із змінами репродуктивного здоров'я у вигляді непліддя і порушенням вегетативного гомеостазу у вигляді синдрому вегетативної диссункції та соматоформної дисфункції вегетативної нервової системи за гіпотонічним типом.

їновими кислотами і є маркером ОС. Високі показники МДА розглядають як маркери тяжкості ОС.

Результати проведених досліджень концентрації МДА показали його збільшення у всіх групах обстежених жінок із ПВГ та ЗР3 (табл. 1). При цьому серед вторинних про-

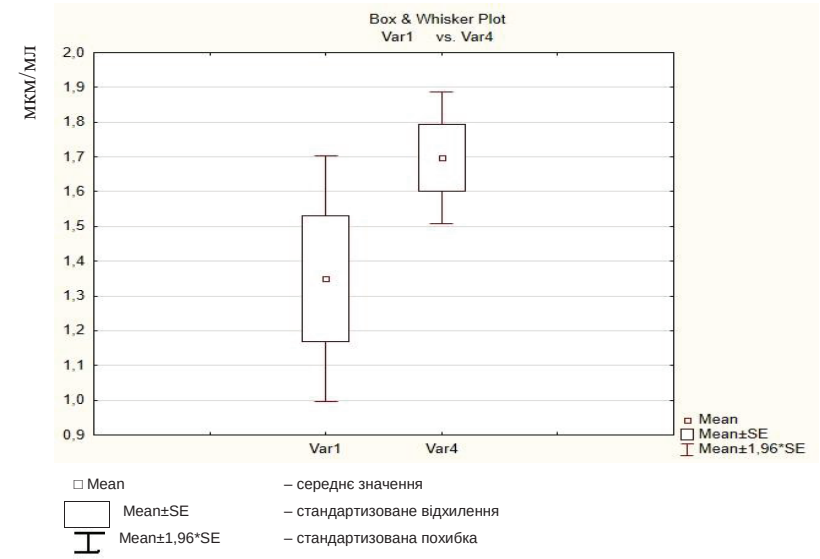

Умовні позначення: Var1 - розмах середнього значення вибірок і їх стандартизовані похибки показника вмісту гідроперекисів у крові жінок із непліддям та соматоформною диссункцією вегетативної нервової системи за кардіальним типом; Var4 - розмах середнього значення вибірок і їх стандартизовані похибки показника вмісту гідроперекисів у крові жінок із непліддям та синдромом вегетативної дисфуннції.

Рис. 2. Діаграма розмаху середніх значень вибірок та їх стандартизовані похибки показника вмісту гідроперекисів у крові жінок зі змінами репродуктивного здоров'я у вигляді непліддя і порушенням вегетативного гомеостазу у вигляді синдрому вегетативної диссуункції та соматоформної дисфрункції вегетативної нервової системи за кардіальним типом.

дуктів ПОЛ концентрація МДА також підвищувалася, але не була найбільшою серед таких показників у жінок із ПРЗ та СВД (табл. 1). Концентрація МДА у жінок із СДВНС за гіпертонічним типом, що перенесли артифріційний аборт,

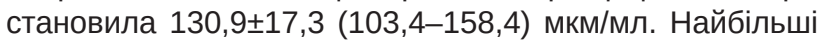


показники МДА спостерігались у жінок I групи 1-ї та 2-ї підгруп, а також у жінок III групи 3-ї підгрупи та жінок IV групи 3-ї підгрупи. Дещо нижчі, але також значно збільшені показники МДА реєструвалися в жінок I групи 3-ї підгрупи, II групи 3-ї підгрупи, III групи 2-ї підгрупи й у жінок IV групи 1-ї та 3-ї підгруп.

Збільшення рівня МДА спостерігалось також у жінок, що перенесли артифріційний аборт, при порівнянні цього показника у таких жінок із різними ПВГ (рис. 3).

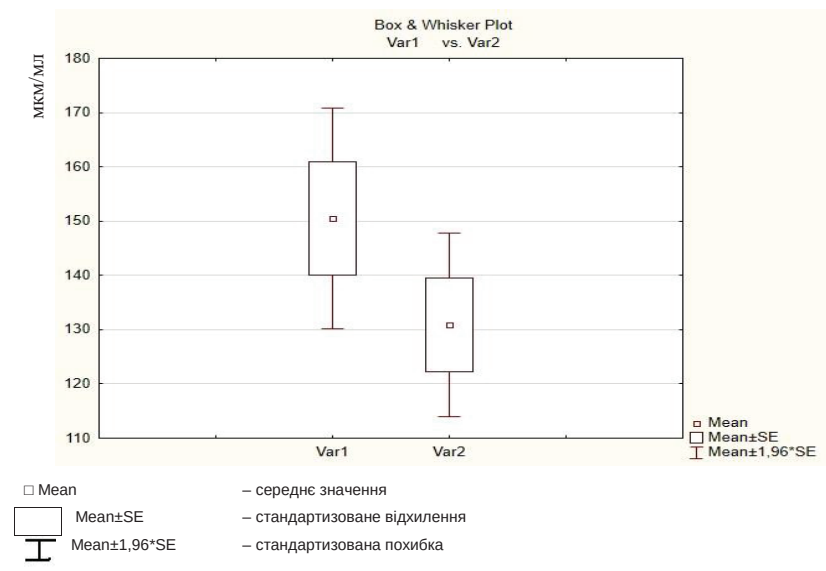

Умовні позначення: Var1 - розмах середнього значення вибірок і їх стандартизовані похибки показника вмісту малонового діальдегіду в крові жінок, що перенесли артифіційний аборт та із синдромом вегетативної диссрункції; Var2 - розмах середнього значення вибірок і їх стандартизовані похибки показника вмісту малонового діальдегіду в крові жінок, що перенесли артифріційний аборт та із соматофрормною дисфункцією вегетативної нервової системи за гіпертонічним типом.

Рис. 3. Діаграма розмаху середніх значень вибірок та їх стандартизовані похибки показника вмісту малонового діальдегіду в крові жінок зі змінами репродуктивного здоров'я у вигляді стану після перенесеного артисріційного аборту і порушенням вегетативного гомеостазу у вигляді синдрому вегетативної диссрункції та соматофрормної диссрункції вегетативної нервової системи за гіпертонічним типом.

ВИСНОВКИ. 1. У жінок фрертильного віку зі змінами репродуктивного здоров'я порушення вегетативного гомеостазу викликають розпад фоссроліпідів та нейтральних ліпідів клітинних мембран.

2. Стресорні механізми порушення вегетативного гомеостазу мають сильну короткочасну дію на клітинну мембрану шляхом збільшення концентрацій первинних продуктів розпаду фросфоліпідів.

3. Порушення вегетативного гомеостазу в жінок фертильного віку зі змінами репродуктивного здоров'я має тривалий не виражений дестабілізуючий вплив, унаслідок чого підвищується кількість вторинних продуктів перекисного окислення ліпідів.

4. Оксидативний стрес $є$ важливим патогенетичним механізмом розвитку змін репродуктивного здоров'я у жінок із соматоформними захворюваннями та порушенням вегетативного гомеостазу.

ПЕРСПЕКТИВИ ПОДАЛЬШИХ ДОСЛІДЖЕНЬ. ПрОблема репродуктивного здоров'я населення України за-
Достовірність цих результатів підтверджувалась аналізом значення стандартного відхилення середнього рівня МДА в крові жінок, що перенесли артиоріційний аборт на тлі СВД, порівняно з такими жінками, що мали СдВНС за гіпертонічним типом.

Такі ж результати отримані при порівнянні значення стандартного відхилення середнього рівня МДА в крові жінок із непліддям на тлі СВД порівняно з такими жінками, що мали СДВНС за гіпертонічним типом (рис. 4).

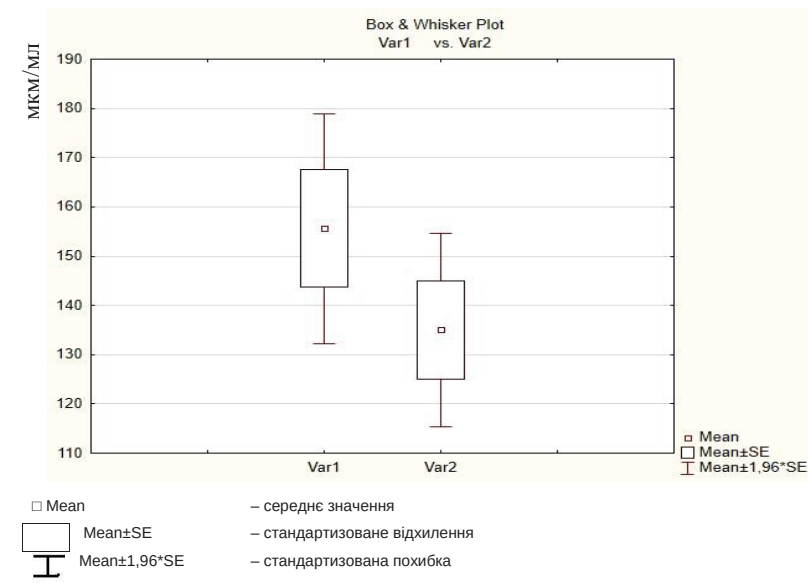

Умовні позначення: Var1 - розмах середнього значення вибірок і їх стандартизовані похибки показника вмісту малонового діальдегіду в крові жінок із непліддям та синдромом вегетативної дисфункції; Var2 - розмах середнього значення вибірок і їх стандартизовані похибки показника вмісту малонового діальдегіду в крові жінок із непліддям та соматофрормною диссункцією вегетативної нервової системи за гіпертонічним типом.

Рис. 4. Діаграма розмаху середніх значень вибірок і їх стандартизовані похибки показника вмісту малонового діальдегіду в крові жінок зі змінами репродуктивного здоров'я у вигляді непліддя та порушенням вегетативного гомеостазу у вигляді синдрому вегетативної диссрункції і соматофрормної дисфункції вегетативної нервової системи за гіпертонічним типом.

лишається найбільш актуальною. Складність вирішення питань, що визначають цю проблему, обумовлена не тільки безпосередньо станом здоров'я населення нашої країни та її складовою репродуктивного здоров'я, але і значною кількістю фракторів ризику, що мають вплив на розвиток порушень репродукції.

Частота функціональних захворювань серцево-судинної системи та інших соматоформних захворювань із ПВГ зростає з кожним роком. Це пов'язано, насамперед, із змінами в умовах існування сучасної жінки. Стресорне навантаження на організм жінок зростає через тягар соціальних негараздів, що може бути патогенетичним механізмом розвитку порушень, як вегетативного гомеостазу, так і репродуктивного здоров'я у ЖФВ. Тому важливим $€$ вивчення не тільки стресорних механізмів розвитку патології вегетативного гомеостазу, а також подальше вивчення і генетично обумовлених змін в організмі та пов'язаних із цим репродуктивних порушень на тлі соматофрормних захворювань. 
Відомо, що вегетативна нервова система відіграє значну роль у забезпеченні гомеостазу організму різних фрорм орізичної і психічної діяльності, бере участь у роботі серцево-судинної, дихальної та інших найбільш важливих систем організму. Проведені дослідження показали вплив цієї системи на обмін речовин, зокрема на стан ПОЛ та розвиток ОС. У подальшому важливим $є$ проведення досліджень із використанням отриманих результатів, направлених на розробку лікувально-профрілактичних заходів на нормалізацію вегетативного гомеостазу та зниження негативного впливу ОС на організм жінок із ЗР3.

\section{СПИСОК ЛІТЕРАТУРИ}

1. Котова О. В. Пациент с психовегетативным синдромом: помогает врач общей практики / О. В. Котова, Л. Н. Максимова // Фарматека. - 2012. - № 19. - С. 36-40.

2. Маховская Т. Г. Соматофрормная дисфрункция вегетативной нервной системы в структуре пограничных психических расстройств (клинико-эпидемиологическое исследование) / Т. Г. Маховская // Российский психиатрический журнал. - 2014. - № 3. - С. 19-22.

3. Оксидативний стрес за умов in vitro, in vivo та можливості його корекції (2013). - URL : http://www.biochemistry. org.ua/index.php/uk/naukovi-seminari-ibkh/scientific-seminarqproblems-of-modern-biochemistryq/1831-06112013.

4. Перекисное окисление липидов (2015). - URL : https://ru.wikipedia.org/wiki/\%d0\%9f\%d0\%b5\%d1\%80\%d0 \%b5\%d0\%ba\%d0\%b8\%d1\%81\%d0\%bd\%d0\%be\%d0\%b5 \%d0\%be\%d0\%ba\%d0\%b8\%d1\%81\%d0\%bb\%d0\%b5\% do\%bd\%d0\%b8\%d0\%b5_\%d0\%bb\%d0\%b8\%d0\%bf\%d0 $\%$ b8\%d0\%b4\%d0\%be\%d0\%b2.

5. Владимиров Ю. А. Перекисное окисление липидов в биологических мембранах / Ю. А. Владимиров, А. И. Арчаков. - М. : Наука, 1972. - 252 с.

6. Барабой В. А. Перекисное окисление и радиация / В. А. Барабой, В. Э. Орел, И. М. Карнаух. - К. : Наукова думка, 1991. - 256 с.

7. А. С. 1303938 СССР, МКИ³ 01/33/48. Способ определения продуктов перекисного окисления липидов в крови / В. Н. Ушкалова, Г. Д. Кадочникова (СССР). - № 3933845/2813; заявл. 17.07.85; опубл. 15.04.87, Бюл. № 14

8. Перекисное окисление липидов. - URL : https://bio. wikireading.ru/7792.

9. Перекисное окисление липидов. - URL : http://trinita.ru/ info/antioksidanty/perekisnoe_okislenie_lipidov.php.

10. Заварзина В. А. Вільно-радикальні процеси при експериментальній ішемії головного мозку. Продукти перекисного окислення ліпідів (дієнові кон'югати, ТБК-реактанти, шіффови підстави) : дипломна робота / В. А. Заварзина. -2008.

11. Чеснокова Н. П. Типові патологічні процеси / Н. П. Чеснокова. - Саратов : Саратовський медичний університет, 2004. - С. 132-136.

12. Стан перекисного окислення ліпідів, антиоксидантного захисту крові у хворих на інфраркт міокарда, обтяжений недостатністю кровообігу / Н. І. Тарасов, А. Т. Тепляков, Є. В. Малаховіч [та ін.] // Тер. архів. - 2002. - № 12. - С. 12-15.

13. Стальная И. Д. Метод определения диеновых коньюгатов, ненасыщенных жирных кислот / И. Д. Стальная //
Современные методы в биохимии. - М. : Медицина, 1977. - C. 63-67.

14. Костюк В. А. Спектрофотометрическое определение диеновых конъюгатов / В. А. Костюк, А. И. Потапович, Е. Ф. Лунец // Вопросы медицинской химии. - 1984. - Т. XXX, № 4. - С. 125-127.

15. Курашвили Л. В. Современное представление о перекисном окислении липидов и антиоксидантной системе при патологических состояниях : метод. пособ. / Л. В. Курашвили, Г. А. Косой, И. Р. Захарова. - Пенза : Ин-т усоверш. врачей M3 РФ, 2003. - 32 c.

16. Вміст продуктів перекисного окислення ліпідів в плазмі крові вагітних жінок. - URL : http://ukrefs.com.ua/ page,3,124047-Soderzhanie-produktov-perekisnogo-okisleniyalipidov-v-plazme-krovi-beremennyh-zhenshin.html.

17. Малоновый диальдегид. - URL : http://www.likar.info/ analyse/malonovyj-dialdegid/.

18. Малоновый диальдегид в крови. - URL : http://www. helix.ru/kb/item/06-185.

19. Вдовиченко Ю. П. Лікування ановуляторного безпліддя за наявності гормонально-імунологічних порушень / Ю. П. Вдовиченко, А. Д. Вітюк // Здоровье женщины. - 2011. - № 8 (64). - C. 180-183.

20. Rates of complication in first-trimester manual vacuum aspiration abortion done by doctors and mid-level providers in South Africa and Vietnam: a randomised controlled equivalence trial / I. K. Warriner, O. Meirik, M. Hoffman [et al.] // Lancet. 2006. - Vol. 368. - P. 1965-1972.

21. Induced abortion: incidence and trends worldwide from 1995 to 2008 / G. Sedgh, I. H. Shah, E. Ahman [et al.] // Lancet. - 2012. - Vol. 379 (9816). - P. 625-632. [doi: 10.1016/S01406736(11)61786-8. Epub 2012 Jan 19].

22. Подольский Вл. В. Психосоматическая характеристика состояния здоровья женщин фертильного возраста с бесплодием, сопровождающимся нарушениями вегетативного гомеостаза / Вл. В. Подольский // Репродуктивное здоровье. Восточная Европа. - 2016. - Т. 6, № 2. - С. 178-185.

23. Подольский Вл. В. Распространенность нарушений вегетативного гомеостаза (вегето-сосудистой дистонии) среди женщин фертильного возраста / Вл. В. Подольский // Репродуктивное здоровье. Восточная Европа. - 2015. № 4 (40). - C. 45-52.

24. Подольський Вл. В. Вегетативний гомеостаз та його порушення в жінок фертильного віку зі змінами репродуктивного здоров'я / Вл. В. Подольський // Перинатология и педиатрия. - 2015. - № 3 (63). - С. 38-46. 


\section{REFERENCES}

1. Kotova, O.V., \& Maksimova, L.N. (2012). Patsiyent s psikhovegetativnym sindromom: pomogayet vrach obshchey praktiki [A patient with psycho-vegetative syndrome: a general practitioner helps]. Farmateka - Pharmateca, 19, 36-40 [in Russian].

2. Makhovskaya, T.G. (2014). Somatoformnaya disfunktsiya vegetativnoy nervnoy sistemy $v$ strukture pogranichnykh psikhicheskikh rasstroystv (kliniko-epidemio- logicheskoye issledovaniye) [Somatoform dysfunction of the autonomic nervous system in the structure of borderline mental disorders (clinica and epidemiological study)]. Rossiyskiy psikhiatricheskiy zhurnal - Russian Psychiatric Journal, (3), 19-22.

3. Oksydatyvnyi stres za umov in vitro, in vivo ta mozhlivosti yoho korektsii [Oxidative stress for the brain in vitro, in vivo and possibility of its correction]. (2013). Retrieved from: http://www. biochemistry.org.ua/index.php/uk/naukovi-seminari-ibkh/scientific-seminar-qproblems-of-modern-biochemistryq/1831-06112013 [in Ukrainian].

4. Perekisnoye okisleniye lipidov [Peroxide oxidation of lipids]. (2015). Retrieved from: https://ru.wikipedia.org/wiki/\%d 0\%9f\%d0\%b5\%d1\%80\%d0\%b5\%d0\%ba\%d0\%b8\%d1\%81\% d0\%bd\%d0\%be\%d0\%b5_\%d0\%be\%d0\%ba\%d0\%b8\%d1\%8 1\%d0\%bb\%d0\%b5\%d0\%bd\%d0\%b8\%d0\%b5 \%d0\%bb\%d0 \%b8\%d0\%bf\%d0\%b8\%d0\%b4\%d0\%be\%d0\%b2 [in Russian].

5. Vladimirov, Yu.A., \& Archakov, A.I. (1972). Perekisnoye okisleniye lipidov $v$ biologicheskikh membranakh [Peroxide oxidation of lipids in biological membranes]. Moscow: Nauka [in Russian].

6. Baraboy, V.A., Orel, V.E., \& Karnaukh, I.M. (1991). Perekisnoye okisleniye $i$ radiatsiya [Peroxide oxidation and radiation]. Kyiv: Naukova Dumka [in Russian].

7. Ushkalova, V.N., \& Kadochnikova, G.D. (1987). Sposob opredeleniya produktov perekisnogo okisleniya lipidov $v$ krov [Method for determining the products of lipid peroxidation in the blood]. USSR №3933845/28-13 1303938 [in Russian].

8. Perekisnoye okisleniye lipidov [Peroxide oxidation of lipids]. Retrieved from: https://bio.wikireading.ru/7792 [in Russian].

9. Perekisnoye okisleniye lipidov [Peroxide oxidation of lipids]. Retrieved from: http://trinita.ru/info/antioksidanty/perekisnoe_okislenie_lipidov.php [in Russian].

10. Zavarzyna, V.A. (2008). Vilno-radykalni protsesy pry eksperymentalnii ishemii holovnoho mozku. Produkty perekysnoho okyslennia lipidiv (Diiienovi koniuhaty, TBK-reaktanty, shiffovi pidstavy) [Free-radical processes in experimental cerebral ischemia. Lipid peroxidation products (conjugated diene, TBAreagents, shiffovy grounds)]. Graduate thesis [in Ukrainian].

11. Chesnokova, N.P. (2004). Typovi patolohichni protsesy [Typical pathological processes]. Saratov: Saratovskyi medychnyi universytet [in Ukrainian].

12. Tarasov, N.I., Teplyakov, A.T., \& Malakhovich, Ye.V. (2002). Stan perekysnoho oksylenyia lipidiv, antyoksydantnoho zakhystu krovi u khvorykh na infarkt miokarda, obtiazhenym nedostatnistiu krovoobihu [State peroxidation of lipids, antioxidant blood in patients with myocardial infarction, aggravated by heart failure]. Ter. Arkhiv - Ter. Archieve, (12), 12-15 [in Ukrainian].

13. Stalnaya, I.D. (1977). Metod opredeleniya diyenovykh kanyugatov, nenasyshchennykh zhirnykh kislot [Method for determination of dienic canugates, unsaturated fatty acids].
Sovremennyye metody v biokhimii - Modern Methods in Biochemistry, Moscow: Meditsina [in Russian].

14. Kostyuk, V.A., Potapovich, A.I., \& Lunets, Ye.F. (1984). Spektrofotometricheskoye opredeleniye diyenovykh konyugatov. [Spectrophotometric determination of diene conjugates]. Voprosy meditsinskoy khimii - Issues of Medical Chemistry, XXX (4), 125-127 [in Russian].

15. Kurashvili, L.V., Kosyy, H.A., \& Zakharova, I.R. (2003). Sovremennoe predstavlenie o perekysnom okyslennii lipidov i antioksidantnoy sistemy pri patologicheskikh stanakh [Modern understanding of lipid peroxidation and antioxidant system in pathological conditions]. Metodychnyy posibnyk. Penza: Ins-t usoversh. Vrachey MZ RF [in Russian].

16. Zmist produktiv perekysnoho okyslennya lipidiv v plazmi krovi vahitnykh zhinok [The content of lipid peroxidation products in the blood plasma of pregnant women]. - URL: http://ukrefs. com.ua/page,3,124047-Soderzhanie-produktov-perekisnogookisleniya-lipidov-v-plazme-krovi-beremennyh-zhenshin.html [in Ukrainian]

17. Malonovyy dialdegid [Malon dialdehyde]. Retrieved from: http://www.likar.info/analyse/malonovyj-dialdegid/ [in Russian].

18. Malonovyy dialdegid $v$ krovi [Malondialdehyde in the blood]. Retrieved from: http://www.helix.ru/kb/item/06-185 [in Russian].

19. Vdovychenko, Yu.P., \& Vitiuk, A.D. (2011). Likuvannia anovuliatornoho bezpliddia za naiavnosti hormonalno-imunolohichnykh porushen [Treatment of anovulatory infertility in the presence of hormone-immune disorders]. Zdorovye zhenshchiny - Woman's Health, 8 (64), 180-183 [in Ukrainian].

20. Warriner, I.K., Meirik, O., \& Hoffman, M. (2006). Rates of complication in first-trimester manual vacuum aspiration abortion done by doctors and mid-level providers in South Africa and Vietnam: a randomised controlled equivalence trial. Lancet, 368, 1965-1972.

21. Sedgh, G., Shah, I.H., Ahman, E., Henshaw, S.K., \& Bankole, A. (2012). Induced abortion: incidence and trends worldwide from 1995 to 2008. Lancet. 379 (9816), 625-632 [doi: 10.1016/S0140-6736(11)61786-8. Epub 2012 Jan 19].

22. Podolskiy, VI.V. (2016). Psykhosomatycheskaya kharakteristika sostoyaniya zdorovya zhenshchin fertylnogo vozrasta s besplodiem, soprovozhdayushchymsya narusheniyami vegetativnogo gomeostaza [Psychosomatic characteristics of the status of health of childbearing age women with infertility,accompanied with violation vegetative homeostasis]. Reproduktivnoe zdorovye. Vostochnaya Evropa - Vegetative Health. Eastern Europe, 6 (2), 178-185.

23. Podolskiy, VI.V. (2015). Rasprostranennost narusheniy vegetativnogo gomeostaza (vegeto-sosudistoy distonii) sredi zhenshchin fertilnogo vozrasta [The prevalence of vegetative homeostasis (vegeto-vascular dystonia) disorders among women of fertile age]. Reproduktivnoye zdorovye. Vostochnaya Yevropa - Vegetative Health. Eastern Europe, 4 (40), 45-52.

24. Podolskyi, VI.V. (2015). Vehetatyvnyi homeostaz ta yoho porushennia u zhinok fertylnoho viku z zminamy reproduktyvnoho zdorovya [Vegetative homeostasis and its disorders in women of childbearing age with changes in reproductive health]. Perinatologiya i pediatriya - Perinatology and Pediatrics, 3 (63), 38-46 [in Ukrainian]. 